\title{
Conceptual foundations of formation of the public administration system in legal education
}

\section{Polyakova O. S., National Defence University of Ukraine named after Ivan Chernyahovsky}

The urgency of the chosen topic is due to the insufficient development of the methodology of public administration of legal education in Ukraine, the need for its conception, the definition of the structure, the mechanism of influence on cognition and practice. In this regard, the necessity of creating the conception of legal education development as a comprehensive detailed long-term course of Ukraine aimed at achieving the main goal of law-education activity - enhancement of legal culture and legal consciousness of the population is substantiated.

The article presents the meaning of the conception for the field of knowledge of public governance and administration and proposes to consider it as a normative legal document, which defines the mission and development ideas, reflects the vision of the existing state of a particular process or phenomenon. The block diagram of the development of the conception of public administration in legal education in Ukraine is proposed. The structure of the conception which confirms its scientific character is defined: substantiation of the conception of the goal and directions of the conception realization; tasks concerning realization of directions defined in the conception; identification of steps (ways, measures, methods), the responsibles and timing of implementation; expected results.

The factors influencing the formation of a high level of legal culture and citizens' legal consciousness are determined, the most actual problems that are characteristic for the modern stage of Ukrainian society development are outlined. The structure of general goals and directions concerning the development of legal education in Ukraine is presented. The functions to be performed by the public administration system in the development of legal education (forecasting, planning, organizational, coordinational, regulating, accounting, controlling, informing, explanatory, propaganda, diagnostic, compensatory) are determined.

It is proved that the conception should represent a system of views on the development of legal education, the formation of a state policy on the development of legal literacy of the population, consolidation of efforts of state authorities and government, local self-government and various civil society organizations in shaping legal knowledge, raising the level of legal culture and legal awareness of citizens.

Keywords: public administration; public governance; legal education; concept; methodology

\section{Концептуальні засади формування системи публічного управління правовою освітою}

\section{Полякова О. С., Національний університет оборони України ім. І. Черняховського}

В статті обгрунтовано необхідність розробки концепції розвитку правової освіти як детального всеохоплюючого довгострокового курсу України, спрямованого на досягнення головної мети правоосвітньої діяльності - підвищення правової культури і правової свідомості населення. Визначено структуру концепції, яка підтверджує її науковість, а також чинники, що впливають на формування високого рівня правової культури та правосвідомості громадян. Окреслено найактуальніші проблеми, притаманні сучасному етапу розвитку українського суспільства, наведено структуру загальних цілей і напрямів публічного управління щодо розвитку правової освіти в Україні. Визначено функції, які має виконувати система публічного управління щодо розвитку правової освіти.

Доведено, що концепція має представляти систему поглядів на забезпечення розвитку правової освіти, формування державної політики щодо розвитку правової грамотності населення, консолідацію зусиль органів державної влади та управління, органів місцевого самоврядування та різноманітних організацій громадянського суспільства у формуванні правових знань, підвищення рівня правової культури та правосвідомості громадян.

Ключові слова: публічне управління; державне управління; правова освіта; конщепиія; методологія 


\section{Концептуальные основы формирования системы публичного управления правовым образованием}

\section{Полякова О. С., Национальный университет обороны Украины им. И. Черняховского}

В статье обоснована необходимость разработки концепции развития правового образования как детального всеобъемлющего долгосрочного курса Украины, направленного на достижение главной цели правообразовательной деятельности - повышение правовой культуры и правового сознания населения. Определена структура концепции, которая подтверждает ее научность, а также факторы, влияющие на формирование высокого уровня правовой культуры и правосознания граждан. Выделены наиболее актуальные проблемы, присущие современному этапу развития украинского общества, приведена структура общих целей и направлений публичного управления по развитию правового образования в Украине. Определены функции, которые должна выполнять система публичного управления для развития правового образования.

Доказано, что концепция должна представлять систему взглядов на обеспечение развития правового образования, формирования государственной политики по развитию правовой грамотности населения, консолидации усилий органов государственной власти и управления, органов местного самоуправления и различных организаций гражданского общества в формировании правовых знаний, повышение уровня правовой культуры и правосознания граждан.

Ключевые слова: публичное управление; государственное управление; правовое образование; концепиия; методология

\section{Problem setting.}

The current stage of methodological development of public administration in legal education in Ukraine is characterized by the need for its concept, for the definition of its structure, for the mechanism of influence on development of knowledge and practice. Despite the previously accumulated methodological potential, which is mostly worked up, the practice of its introduction poses new challenges that are difficult to solve within the framework of the current methodological approaches. Insufficient development of the methodology of public administration in general and public administration in legal education in particular is due to the fact that Ukraine as a sovereign independent state acts for the first time as an object of scientific research, and public administration - as a branch of knowledge. It should be noted that according to the resolution of the Cabinet of Ministers of Ukraine No. 266 dated April 29, 2015, to the «List of sciences and specialties on which the training of applicants for higher education is carried out», instead discipline 1501 «Public Administration» discipline 28 "Public governance and administration" was introduced, which, in the first place, stimulates the development of the corresponding methodology. Of course, during the period of independence in the scientific field of public administration there has been 44 a process of accumulation of methodological values, verification and comprehension of their possibilities in cognition and in practice. Under the new conditions, a problem of modernization of the accumulated methodology emerges in the sphere of governing the state as a whole, as well as administaring legal education in particular.

Recent researches and publications analysis.

The various aspects of the formation and development of the national legal education system are the subject of study of a significant number of Ukrainian scholars (I. Alekseyeva, B. Andrusyshyn, V. Vodnyk, S. Gladky, A. Guz, I. Ishchuk, O. Kovalska, O. Kostenko, D. Kumkov, N. Lyapunova, O. Mashkevsky, B. Melekh, S. Nemchenko, N. Onishchenko, O. Orlova, O. Plakhotnyk, I. Sopilko, N. Storchak, M. Trebin, V. Turyanitsa, G. Useinova, O. Fatkhutdinova, V. Cherevatyuk, $\mathrm{S}$. Shefel and others). Beyond the attention of researchers remains the issue of developing a conceptual framework for the formation of a public administration system in legal education in Ukraine.

The purpose of the article is to develop the conceptual foundations for the formation of a system of public administration in legal education and to substantiate the need to work out a concept for the development of legal education. 


\section{Paper main body.}

Functioning of any sphere is provided by a number of government policy documents, among which the concept occupies an important place. According to the explanatory dictionary, the concept (lat. conceptus - concept, thought, perception) is a formulation, general concept, thought; the conception (lat. concenptio) is a system of evidences of a certain position, a system of views on a particular phenomenon; the ideological idea of the work [6, p. 303]. From a philosophical point of view, the conception is a definite way of understanding, the interpretation of any subject, phenomenon, process, the main point of view on an object or phenomenon, a guiding idea for their systematic coverage. This term is also used to refer to the main idea, constructive principle in scientific, artistic, technical, political and other activities $[10$, p. 278]. In legal science, the conception is considered as "a plan defining a strategy of actions in implementing reforms, projects, plans and programs; a system of views on processes and phenomena in nature and society" [1, p. 356].

As for the field of knowledge of public administration, according to O. Obolensky, the conception is "a set of views, a way of understanding, interpreting a separate subject of study, phenomena and processes, the leading idea of their system theoretical and methodological characteristics; the leading plan that defines a strategy for implementing reforms, programs, and plans" [3, p. 174]. According to V. Malynovsky, the conception is a document developed by the state authorities in order to identify the main principles (directions, priorities of implementation of the state policy in the relevant sphere, which provides for measures to solve a specific problem [5, p. 97]. As Yu. Didok says, the conception is "a way of understanding, interpreting processes or phenomena; a system of evidences of a particular position, a set of views on a particular subject of study, a doctrine, a theoretical direction or approach, a leading idea; the form of the leading ideological plan during the formation of the state policy or the document developed and approved in accordance with the established procedure". In public administration it is considered appropriate to pre-design a scientifically grounded conception for all significant political and legislative decisions" [4].
All of the above, one can conclude that the conception in the field of public governance and administration knowledge can be considered in the following meanings: as a document produced by public authorities during the formation of the state policy; as a way of scientific cognition of a particular management process or of a certain phenomenon, which are influenced administratively; as a managerial structure containing a general system understanding of the ways of transition from the current position of the administered object to the desired.

Note that in the managerial field, the conception is generally considered as a normative legal document that reflects the vision of the existing state of a particular process or phenomenon, defines the mission and development ideas. This document, though it is the most general, abstract, however, even as a project, it can affect management activity. In this aspect, the conception is, as a rule, a threelevel document (Fig. 1):

- at the first level (all-national, national) a general description and assessment of the state of the object of management is carried out, the most general patterns of formation and functioning of the desired model are determined;

- at the second level (central) - the first level document is taken as a basis and the theoretical substantiation of the development of key elements is formed, the so-called scenario of development is created;

- the third level (regional, local) is the most most tangible to the situation, so here specific problems, possible solutions to them, action plans are identified.

It should be noted that in Ukraine during the whole period of its independence, a number of normative legal acts regulating law-education activities have been adopted. However, despite their large number, legal education still remains devoid of a holistic regulation system built on a single logic of formation and with a clearly established mutual subordination of various types of documents. Among all existing regulatory acts, those programs [8; 9] which are designed to develop the legal education of the population predominate, however, they are imperfect and contain a number of shortcomings, namely: there is no analysis of the situation; problems, tasks, means and 
ways of achieving the goals, expected results / changes, etc. have not been identified. Thus, during the entire period of independence, a comprehensive general long-term course on the development of legal education aimed at the future with a view to realizing its main purpose, that is, development strategies, has not been developed. At the state level, key benchmarks for the desired model have not been identified. Therefore, in the context of our study, it is expedient to develop a system of scientifically grounded ideas (conceptual foundations) regarding the development of legal education as a separate sphere of life of the society and the system of public administration that regulates the law-education activity in Ukraine.

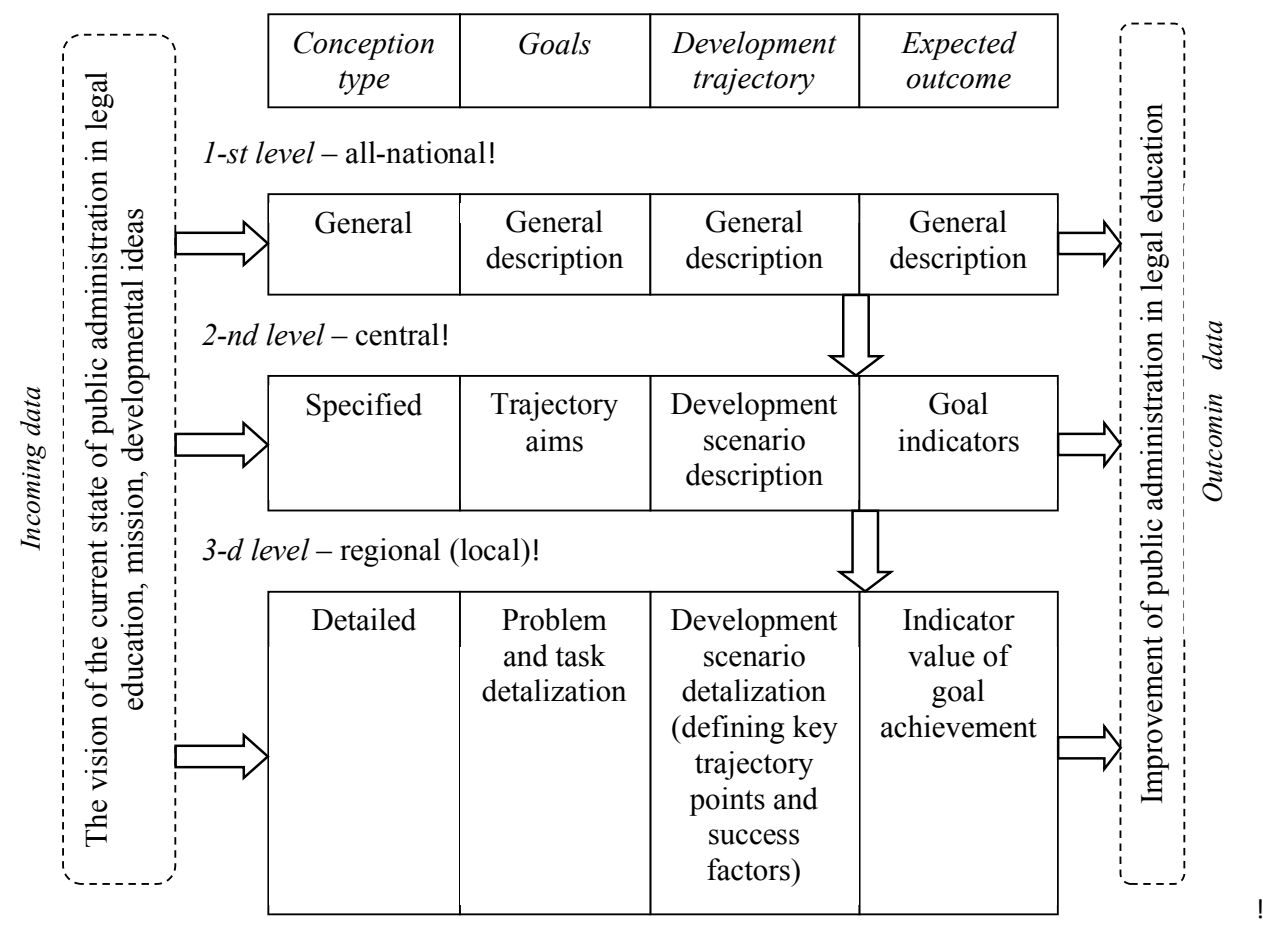

Fig. 1. Block diagram of the conception development for public administration in legal education

It should be noted that there is no definition of a clear structure of such a document, as a conception in the national scientific environment, as well as in practical activity. Usually, developers use the following structure: introduction (preamble, general provisions); problems that need to be addressed; purpose and terms of implementation of the conception; ways and means of solving problems; the main steps for implementing the conception; expected results; the amount of financial, logistical, labor resources that are necessary for the implementation of the document. The identified structure is tentative and is used to develop practically all government documents of the state. However, the fact that both the previous [9], approved in 1995, and the current program document on the development of legal education in the population [8], approved 46 in 2001, have a very strange appearance, with a minimum of structural elements. In particular, the 1995 program consisted of only two sections - "the main directions of legal education and the form of its implementation" and "priority measures for realization of the basic directions of legal education of the population". The current program document consists of three structural elements - "general provisions" and "main directions of program implementation", which outline the text of the whole document, and "main measures to ensure the implementation of the program", which specifies the management activities: defined actions, responsible structures and implementation terms. However, in both cases, the situation in the field of legal education was not described, key issues that require immediate resolution, etc., were not identified. 
We believe that, since the concept is a system of views, it is a way of scientific cognition of a certain management process, then it must necessarily present the justification - the relevance of the development of legal education (determination of the problem, its characterization, estimation of its scale (level, priority), trends and dynamics of the problem development, negative consequences, etc.). In this case, we propose to build a conception for the development of legal education in such a structure: the rationale for the conception topic; goals and directions of the conception implementation; tasks concerning realization of directions defined in the conception; identification of steps (ways, measures, methods), the responsiblse and timing of implementation; expected results. In particular, in the justification of the conception, in our opinion, it is expedient to place the thesaurus, methodological foundations, to determine the factors that influence the formation of a high level of legal culture and citizens' legal awareness, as well as coverage of the results of statistical, sociological, empirical and other studies that show the problem acuteness.

In our opinion, it is necessary to clearly define the basic concepts in the thesaurus, which was emphasized in the scientific writings by the author earlier [2; 7]. In this case, legal education should be considered not as a component of the education system (as defined in the current program document) which limits its functionality, but as a process of purposeful transfer of knowledge, skills and the formation of sustainable skills in the field of legal reality, which allow to have not only theoretical ideas about certain legal norms of life, laws of the country, but also to use this knowledge in practice. At the same time, it is imperative to emphasize that legal education is not aimed at young people only, it affects the formation and increase of the level of legal consciousness and legal culture of the entire population of the country. It should also be noted that legal education and legal upbringing are organically interconnected. Educational process involves the continuity of the interrelation of these processes, where the object of influence is legal consciousness, and the final result - the legal culture of a person.
In methodological terms, it is first necessary to determine the role of legal education, which it plays at the present stage of development of the country. In particular, it should be noted that in Ukraine the highest social value is a person, his life and health, honor and dignity, safety and inviolability. The state is responsible for its activities to the person, guarantees and provides his rights and freedoms, ensures the rule of law and the development of democratic governance, the formation of a rule of law and developed civil society, which necessitates the increase of the legal culture and legal consciousness of the citizens of the country. All this can be realized in the country in the case of the construction of an effective system of legal education, which should be multistage and cover the entire life cycle of a person, starting from his birth.

The factors influencing the formation of a high level of legal culture and citizens' legal awareness are as follows:

- the nature of upbringing and the moral climate in the family, the law-abiding behavior of parents;

- a high level of teaching of legal knowledge in educational institutions of different levels and types on a free basis; consolidation and development of the basics of legal education and legal culture in the education curriculum;

- popularization among the population of education for democratic citizenship and human rights education, the development of appropriate competences for education workers, youth and local partners; raising the level of the culture of democracy of the population; introduction of activities aimed at involving young people in community-based activities;

- improvement of legal education for professional training of a lawyer in accordance with European standards of higher education and legal profession;

- establishment of humanistic legal ideas, universal human and national legal values, high moral principles in public life;

- promoting self-education of the population on issues of law and public administration;

- clarity, accessibility and effectiveness of legislation, its adequate correspondence with the political and socio-economic situation in 
the state; ensuring the principles of justice and equality at the legislative level, compliance to the interests and needs of different social groups;

- dissemination and use of informative materials (printed materials, electronic and audio-visual information, mass-media, etc.) accessible for perception, which form legal literacy and legal awareness of the population; providing everyone with access to information and knowledge about the rights, freedoms and responsibilities of a person and citizen, mechanisms for the implementation of the protection of such rights and freedoms;

- effective prevention and counteraction to corruption, strengthening of institutional capacity and improvement of European practices;

- full functioning of the judiciary system in accordance with European standards, the efficiency of justice, including the separate specialized courts; expanding the Ombudsman's office to effectively address a wide range of human rights violations through the use of extra-judicial means;

- legal, professional, effective activity of law enforcement agencies in detecting, preventing and stopping crimes; maintenance of law and order in vital spheres of life for the majority of citizens;

- availability of qualified legal aid to citizens; creation of conditions for the functioning of legal clinics, laboratories, etc.;

- fulfillment of regulatory requirements by organizations that carry out the sale of goods and provide services to the population;

- accessibility and clarity of services provided by the system of public authorities to the population; strict compliance with the rules of law and professional ethics of civil servants and officials of local self-government bodies;

- creation of appropriate conditions for legal and social adaptation of internally displaced persons who have moved from the temporarily occupied territories of Ukraine and participants of combat operations (participants in the antiterrorist operation and operations of the united forces), ensuring the realization and protection of their rights, meeting educational needs;
- coordination of activities of the state authorities and administrative bodies, local selfgovernment bodies, associations of citizens, educational establishments, culture, scientific institutions, publishing organizations, mass media in organization and implementation of law-education activity;

- activities of persons of creative professions, their associations, the media, organizers of broadcast and cable broadcasting, publishing organizations, producers of advertising products, aimed at creating and disseminating information (work, product) that affects the formation of legal awareness;

- international cooperation in the field of human rights and legal education.

As for the analysis of the current situation, it should be noted that this is partially (very briefly) written in the current program document [8]. We outline only those problems that are most urgent at the present stage of the state's development, namely:

- overcoming legal nihilism (low level of legal literacy, legal awareness of citizens);

- low level of legal culture of citizens (low level of awareness of their rights and respect for other people's rights, ignorance of laws);

- low level of citizens' legal awareness (low level or in general lack of skills of positive legal behavior; rejection and unawareness of the system of legal values existing in society);

- high level of crime, especially among young people;

- weak or no civil position of the population;

- low level of legal literacy, legal culture and legal awareness of public servants, officials of local self-government bodies, whose duties include protection of violated rights and prevention of violations;

- insufficient level of training of pedagogical personnel, which provide teaching of courses, disciplines of legal direction;

- lack of an effective mechanism for cooperation in the field of legal education between the system of public authorities and the system of civil society organizations;

- improper use of the scientific and cultural potential of the country as to increasing the level of legal culture and legal consciousness of citizens; 
- often untimely disseminating information to the public about planned changes in the legal system of the society and clarification of their goals;

- absence of a mechanism for monitoring (observing) the state and development of legal education;

- the lack of an assessment of the effectiveness of the legal education management system, etc.

We believe that it is expedient to describe the problem in the document, referring to the results of research in the field of human rights and education, as well as statistical information of state authorities and administration, for example, on the state of crime. In particular, in 2017, the results of a nationwide survey on the perception and understanding of human rights issues in Ukrainian society were laid open to the public
[11]. The problems encountered in the research have to do with various spheres of society's life: legal education, professional judicial education, judicial branch of power, law enforcement agencies, human rights organizations, educational activities, media activities, government bodies and authorities, local government bodies that organize and carry out legal education activities, etc. It only proves that the impact of legal education is comprehensive, inclusive, and, therefore, ensuring its development should be one of the priority areas of the state policy. In accordance with the above block diagram of the development of the conception of public administration in legal education, the key provisions - trajectories (vectors, directions) of development and trajectory goals should be defined. Their indicative structure is given in Table 1.

Table 1. The structure of general goals and directions for the development of legal education in Ukraine

\begin{tabular}{|c|c|}
\hline General goals & Areas of public administration \\
\hline $\begin{array}{l}\text { Formation of respect to the } \\
\text { Constitution of Ukraine, rights } \\
\text { and freedoms of a human and a } \\
\text { citizen, self-esteem, } \\
\text { responsibility before the law for } \\
\text { their actions in society }\end{array}$ & $\begin{array}{l}\text { Development of legal education / legal } \\
\text { upbringing in educational institutions of } \\
\text { different levels through the introduction of } \\
\text { educational courses, programs, teaching } \\
\text { materials, which provide knowledge in the } \\
\text { field of law }\end{array}$ \\
\hline $\begin{array}{l}\text { Increasing the level of legal } \\
\text { culture of citizens, their } \\
\text { awareness and legal literacy }\end{array}$ & $\begin{array}{l}\text { Organization of legal education of the } \\
\text { population and legal informing of citizens }\end{array}$ \\
\hline Overcoming legal nihilism & $\begin{array}{l}\text { Improvement of the system of legal } \\
\text { education and training of qualified lawyers } \\
\text { and pedagogical staff in the field of law }\end{array}$ \\
\hline $\begin{array}{l}\text { Organization of legal education } \\
\text { of a citizen of Ukraine }\end{array}$ & $\begin{array}{l}\text { Formation of national and universal human } \\
\text { values }\end{array}$ \\
\hline $\begin{array}{l}\text { Ensuring the free development of } \\
\text { the individual and the formation } \\
\text { of social and public experience }\end{array}$ & $\begin{array}{l}\text { Transformation in the sphere of culture, } \\
\text { mass media, advertising and publishing } \\
\text { activities aimed at forming a high level of } \\
\text { legal culture and citizens' legal awareness. }\end{array}$ \\
\hline $\begin{array}{l}\text { Creating a system of incentives } \\
\text { to enforce laws as the basic } \\
\text { model of human social behavior }\end{array}$ & $\begin{array}{l}\text { Improvement of the activities of public } \\
\text { authorities, law enforcement agencies aimed } \\
\text { at ensuring the rule of law and order and } \\
\text { increasing the legal awareness of public } \\
\text { servants }\end{array}$ \\
\hline $\begin{array}{l}\text { Implementation in the public } \\
\text { consciousness of the idea of } \\
\text { diligent fulfillment of duties and } \\
\text { legal norms }\end{array}$ & $\begin{array}{c}\text { Improvement of activities in the field of } \\
\text { providing qualified legal assistance, } \\
\text { including the creation of an effective system } \\
\text { of free legal aid }\end{array}$ \\
\hline
\end{tabular}

In our opinion, the system of public administration as to the development of legal education should fulfill the following functions:

- prognostic - systematic study of the state, structure, dynamics and prospects of the development of legal education; development of forecasts, management of them;
- planning - should be carried out at all levels of the management hierarchy, has to determine the purpose, tasks, directions, means of realization of the right of educational activity; development of legal education development programs, with the help of which the main goal should be achieved; 
- organizational - creation of an organizational mechanism, the formation of a leading and lead system, communications and relations between them in order to achieve the goals and objectives in the field of legal education;

- coordination - ensuring the coherence of the whole system of public administration; action coordination of heads of structural units, institutions, offices, organizations, citizens, not only within the system, but also in relation to the external environment;

- regulation - achievement of the necessary state of order and stability of the public administration system; the ability to maintain a balance between disturbing influences (deviations) away from the given trajectory (vector, direction) of the development of legal education;

- registration-collection, communication, storage, processing parameters (data, indicators, criteria, etc.) of legal education, registration and grouping information on the activities of the public administration system of legal education of the population, availability and costs of financial, logistical, human resources;

- control - the systematic observation of the actual status of legal education and the management system in the performance of tasks;

- informational - increase of awareness of the population in legal issues, expansion of access to obtaining legal information;

- explanatory - ensuring the adequacy of the awareness of the reported information, the unity of understanding and the use of common standards in legal issues;

- propaganda - the dissemination and explanation of ideas and conceptions reflecting the interests of social communities and groups;

- diagnostic - study of the qualitative state of development of legal education and public administration system;

- compensatory - organization of managerial and pedagogical personnel training in order to provide them with information, the formation of skills that were not acquired by them in the process of basic vocational education.

In general, the conception should represent a system of views on the development of legal education, the formation of a state policy as to the development of legal literacy of the population, consolidation of efforts of state authorities and management, local governments and various civil society organizations in shaping legal knowledge, raising the level of legal culture and legal awareness of citizens.

\section{Conclusions.}

Thus, the article substantiates the necessity of developing a conception for the development of legal education in Ukraine as a comprehensive inclusive longterm course aimed at achieving the main goal of the legal education - enhancing the legal culture and legal consciousness of the Ukrainian population. The structure of the conception which confirms its scientific character and reflects the vision of both the existing state of legal education and its further development is determined. It is proved that the conception should identify the main priorities for the formation of an effective system of public administration in this field, which depends primarily on the effectiveness of the implementation of law-education in Ukraine. In this regard, the conception should serve as a "corridor» of possible solutions for achieving a common goal in the field of legal education, include alternative models of implementation which, if necessary, can change the priority of implementation, leaving the direction of development unchanged. Based on the developed conception, other government documents should be built - strategies, programs, projects, plans and other legal documents on the development of legal education, the main task of which should be to specify the provisions of this conception.

Further scientific researches of a the problem should be directed to the development of the main steps (ways, measures, methods, mechanisms) of the conception implementation, as well as the definition of expected results and indicators for their measurement. 


\section{БІБЛІОГРАФІЧНІ ПОСИЛАННЯ}

1. Барыхин А. Б. Большая юридическая энциклопедия / А. Б. Барыхин. - М. : Книжный мир, 2010. - 960 с.

2. Бульба В. Г. Визначення сутності поняття «публічне управління правовою освітою» як основа поняття в правоосвітній галузі України / В. Г. Бульба, О. С. Полякова // Державне будівництво: електр. наук. фах. видання - Харків: Вид-во ХарРІ НАДУ «Магістр», 2016. - № 1. - Режим доступу: http://www.kbuapa.kharkov.ua/e-book/db/2016-1/doc/2/02.pdf.

3. Оболенський О. Ю. Державне управління та державна служба: словник-довідник / О. Ю. Оболенський. - Київ: Вид-во КНЕУ, 2005. $-480 \mathrm{c}$.

4. Дідок Ю. В. Концепція / Ю. В. Дідок // Енциклопедія державного управління: у 8 т. - Київ: НАДУ, 2011. - Т. 1. - 2011. - С. 312.

5. Малиновський В. Я. Словник термінів і понять з державного управління / В. Я. Малиновський. - Київ: Атіка, 2005. - 240 с.

6. Новий український тлумачний словник. Близько 20000 слів і словосполучень / укл. Н. Д. Кусайкіна, Ю. С. Цибульник.

- Харків: Книжковий Клуб «Клуб Сімейного Дозвілля», 2008. - 608 с.

7. Полякова О. С. Формування понятійно-категоріального апарату публічного управління правовою освітою в Україні: науково-методологічний підхід / О. С. Полякова // Актуальні проблеми державного управління. - 2016. - № 2. - С. 151-157. 8. Про Національну програму правової освіти населення: Указ Президента України № 992/2001 від 18 жовтня 2001 р. Режим доступу: http://zakon5.rada.gov.ua/laws/show/992/2001.

9. Про Програму правової освіти населення України: постанова Кабінету Міністрів України № 366 від 29 травня 1995 р. Режим доступу: http://zakon2.rada.gov.ua/laws/show/366-95-\%D0\%BF/ed1.

10. Философский энциклопедический словарь / гл. редакция: Л. Ф. Иличев, П. Н. Федосеев, С. М. Ковалев, В. Г. Панов. М.: Сов. Энциклопедия, 1983. - 840 с.

11. Бекешкіна I. Що українці знають і думають про права людини: загальнонаціональне дослідження / I. Бекешкіна, Т. Печончик, В. Яворський та ін. - Київ, 2017. - 308 с.

\section{REFERENCES}

1. Baryhin, A.B. (2010). Bol’shaja juridicheskaja jenciklopedija [Big legal encyclopedia]. Moscow: Knizhnyj mir [in Russian].

2. Bul'ba, V.G., \& Poljakova, O.S. (2016). Viznachennja sutnosti ponjattja «publichne upravlinnja pravovoju osvitoju» jak osnova ponjattja v pravoosvitnij galuzi Ukraini [Definition of the essence of the concept of «public management of legal education» as the basis of the notion in the law-of-education industry of Ukraine]. Derzhavne budivnictvo, 1. Harkiv: Vid-vo HarRI NADU «Magistr». Retrieved from: http://www.kbuapa.kharkov.ua/e-book/db/2016-1/doc/2/02.pdf [in Ukrainian].

3. Obolens'kij, O.Ju. (2005). Derzhavne upravlinnja ta derzhavna sluzhba [Public administration and public service]. Kyiv: Vid-vo KNEU [in Ukrainian].

4. Didok, Ju.V. (2011). Koncepcija [Concept]. Enciklopedija derzhavnogo upravlinnja Teorija derzhavnogo upravlinnja. (Vols. 8). Kyiv: NAPA [in Ukrainian].

5. Malinovs'kij, V.Ja. (2005). Slovnik terminiv i ponjat' z derzhavnogo upravlinnja [Glossary of Terms and Concepts on Public Administration]. Kyiv: Atika [in Ukrainian].

6. Kusajkina, N.D., \& Cibul'nik, Ju.S. (2008). Novij ukraïns'kij tlumachnij slovnik. Bliz'ko 20000 sliv i slovospoluchen [New Ukrainian Explanatory Dictionary. About 20,000 words and phrases]. Harkiv: Knizhkovij Klub «Klub Simejnogo Dozvillja» [in Ukrainian].

7. Poljakova, O.S. (2016). Formuvannja ponjatijno-kategorial'nogo aparatu publichnogo upravlinnja pravovoju osvitoju v Ukraini: naukovo-metodologichnij pidhid [Formation of the conceptual-categorical apparatus of public administration in legal education in Ukraine: scientific and methodological approach]. Aktual'ni problemi derzhavnogo upravlinnja. Magistr, 2, 151-157 [in Ukrainian]. 8. Pro Nacional'nu programu pravovoï osviti naselennja [About the National Program of Legal Education of the Population]. Ukaz Prezidenta Ukrainy № 992/2001 vid 18 zhovtnja 2001 r. Retrieved from: http://zakon5.rada.gov.ua/laws/show/992/2001 [in Ukrainian].

9. Pro Programu pravovoi osviti naselennja Ukraini [About the Program of Legal Education of the Population of Ukraine]. Postanova Kabinetu Ministriv Ukraïni № 366 vid 29 travnja 1995 r. Retrieved from: http://zakon2.rada.gov.ua/laws/show/366-95$\% \mathrm{D} 0 \% \mathrm{BF} / \mathrm{ed} 1$ [in Ukrainian].

10. Ilichev, L.F., Fedoseev, P.N., Kovalev, S.M., \& Panov, V.G. (Eds.). (1983). Filosofskij jenciklopedicheskij slovar [Philosophical Encyclopedic Dictionary]. Moscow: Sov. Jenciklopedija [in Russian].

11. Bekeshkina, I., Pechonchik, T., \& Javors'kij, V. et all. (2017). Shho ukrainci znajut' i dumajut' pro prava ljudini: zagal'nonacional'ne doslidzhennja [What do Ukrainians know and think about human rights: nationwide research]. Kyiv [in Ukrainian].

\section{Полякова Ольга Станіславівна}

Кандидат юридичних наук

Національний університет оборони України ім.

I. Черняховського

03049, м. Київ, Повітрофлотський проспект, 28

Email: ot1323@ukr.net

Цитування: Polyakova O. S. Conceptual foundations of formation of the public administration system in legal education / O. S. Polyakova // Аспекти публічного управління. - 2018. - Т. 6. - № 9. - С. 43-51.

Citation: Polyakova, O.S. (2018). Conceptual foundations of formation of the public administration system in legal education. Public administration aspects, 6 (9), 43-51.

Стаття надійшла / Article arrived: 15.08.2018

\section{Polyakova Olha}

Candidate of Juridical Sciences

National Defence University of Ukraine named after Ivan Chernyahovsky

28, Povitroflotskyi Ave, Kyiv, 03049, Ukraine 